\title{
Interventions of the Psychoanalytic Therapist in the Psychotherapeutic Process of a Patient with Borderline Personality Disorder
}

\author{
Liliam Simoni ${ }^{*}, 1$ \\ Orcid.org/0000-0003-3978-639X \\ Silvia Pereira da Cruz Benetti ${ }^{1}$ \\ Orcid.org/0000-0001-8557-2216 \\ Aline Alvares Bittencourt ${ }^{1}$ \\ Orcid.org/0000-0002-7121-145X
}

${ }^{1}$ Universidade do Vale do Rio dos Sinos, São Leopoldo, RS, Brasil

\begin{abstract}
This study aimed to identify the types of interventions of a psychoanalytic therapist in the psychotherapy of a patient with Borderline Personality Disorder, during a period of treatment prior to psychiatric hospitalization. The Systematic Case Study procedure was adopted with a quantitative design. For the data analysis, twelve sessions of psychotherapy were transcribed and analyzed and the interventions of the therapist were classified based on the Modified Multidimensional Classification of Psychotherapeutic Interventions (CMIP-M), which identifies types of interventions in clinical material. Pairs of independent judges trained in the methodology of the instrument evaluated and classified each of the interventions of the therapist at the descriptive level. The results were presented by means of descriptive statistics of frequency and percentage and indicated predominance of empathic (27.3\%), closed exploratory (24.1\%) and psychoanalytical examination (15.1\%) interventions throughout the investigation process. The results showed similarities with previous studies, indicating the emphasis on closed exploratory interventions in the treatment of personality disorders. However, there were differences in relation to the previous investigations carried out with patients diagnosed with Borderline Personality Disorder, in which expressive interventions predominated.
\end{abstract}

Keywords: Psychoanalytic psychotherapy, psychological intervention, Borderline Personality Disorder.

\section{Intervenções do Terapeuta Psicanalítico no Processo Psicoterapêutico de uma Paciente com Transtorno de Personalidade Borderline}

\section{Resumo}

Este estudo teve por objetivo identificar os tipos de intervenções de um terapeuta psicanalítico na psicoterapia de uma paciente com Transtorno de Personalidade Borderline, em um recorte do tratamento

* Mailing address: Rua Carlos Mariani, 399, Bairro Rio Branco, Caxias do Sul, RS, Brazil 95097-640. E-mail: liliamsimoni@terra.com.br, spcbenetti@gmail.com and alinealvares@hotmail.com 
anterior à sua internação psiquiátrica. O procedimento adotado foi o Estudo de Caso Sistemático com delineamento quantitativo. Para análise dos dados, foram transcritas e analisadas doze sessões de psicoterapia, sendo as intervenções do terapeuta classificadas com base na Classificação Multidimensional de Intervenções Psicoterapêuticas Modificada (CMIP-M), que identifica tipos de intervenções em um material clínico. Duplas de juízes independentes e treinados na metodologia do instrumento avaliaram e classificaram cada uma das intervenções do terapeuta ao nível descritivo. Os resultados foram apresentados por meio de estatísticas descritivas de frequência e percentual e apontaram predominância das intervenções empáticas $(27,3 \%)$, exploratórias fechadas $(24,1 \%)$ e examinativas psicanalíticas $(15,1 \%)$ ao longo do processo investigado. Por um lado, os resultados mostraram semelhanças com estudos anteriores, indicando destaque às intervenções exploratórias fechadas no tratamento de transtornos de personalidade. Por outro lado, evidenciou-se diferenças em relação às investigações anteriores realizadas com pacientes diagnosticados com Transtorno de Personalidade Borderline, nas quais predominaram intervenções expressivas.

Palavras-chave: Psicoterapia psicanalítica, intervenção psicológica, Distúrbio de Personalidade Borderline.

\section{Intervenciones del Terapeuta Psicoanalítico en el Proceso Psicoterapéutico de uno Paciente con Trastorno de Personalidad Limítrofe}

\section{Resumen}

Este estudio ha tenido como objetivo identificar los tipos de intervención de un terapeuta en la psicoterapia psicoanalítica de un paciente con trastorno de personalidad limítrofe, en un recorte del tratamiento previo a su hospitalización psiquiátrica. El procedimiento adoptado fue el estudio de caso sistemático con un diseño cuantitativo. En el análisis de datos, se ha transcripto y analizado doce sesiones de psicoterapia, y las intervenciones del terapeuta clasificadas basadas en la Clasificación Multidimensional de Intervenciones Psicoterapéuticas, versión modificada (CMIP-M), que identifica los tipos de intervenciones en un material clínico. Un par de jueces independientes y entrenados en la metodología del instrumento de evaluación y clasificación de cada una de las intervenciones del terapeuta para el nivel descriptivo. Los resultados se presentaron mediante estadística descriptiva y el porcentaje de frecuencia y revelaron predominio de intervenciones empáticas $(27,3 \%)$, exploratorios cerrada $(24,1 \%)$ y examinativas psicoanalíticas $(15,1 \%)$ en el proceso de investigación. Por un lado, los resultados sugirieron similitudes con estudios previos que indican énfasis en intervenciones cerradas exploratorias en el tratamiento de trastornos de la personalidad. Por otro lado, mostró diferencias en relación a las investigaciones llevadas a cabo con los pacientes diagnosticados con el trastorno de personalidad limítrofe, en la que predominaban las intervenciones expresivas.

Palabras clave: Psicoterapia psicoanalítica, intervención psicológica, trastorno de personalidad limítrofe.

Research into the psychotherapeutic process is a fertile field for investigation and a challenge for researchers and clinical psychotherapists. The clinical practice based on scientific evidence, through the analysis of psychotherapeutic processes and results, improves the clinical work with patients and allows a better understanding of the psychotherapies (Brum et al., 2012; Peuker, Habigzang, Koller, \& Araujo, 2009).

An area that has received significant attention in terms of research, due to the increase in the current clinical demand, is the one related to the investigation of the psychotherapeutic process directed toward severe patients, mainly 
with symptoms associated with the diagnosis of Borderline Personality Disorder (Eizirik \& Fonagy, 2009; Fonagy \& Bateman, 2007; Jordão \& Ramires, 2010). These patients, due to attitudes of impulsivity and aggressiveness, may present difficulties in adherence to the treatments (Tanesi, Yazigi, Fiore, \& Pitta, 2007). Psychotherapy, although difficult to perform and associated with high evasion rates in these cases, is considered appropriate for the treatment of Borderline Personality Disorder (Madeddu, Aquaro, \& Petri, 2012).

For the improvement of psychotherapies in general, one of the aspects extensively investigated in different theoretical models refers to the study of the mechanisms of therapeutic action, in which the contribution of the therapist, the patient and the interaction are highlighted in relation to various aspects that affect the psychotherapies (Peuker et al., 2009). Among the mechanisms of therapeutic action, the variables of the therapist constitute one of the elements relevant for investigation (Goodman, Anderson, \& Diener, 2014), as they can influence the psychotherapy process and its results (Cordioli \& Giglio, 2008).

Some authors understand that the personal characteristics of the therapist have meaning regarding the treatments (Heinomen, Knekt, Jääskeläinen, \& Lindfors, 2014; Lambert, 2013). Lambert (2013) proposed that among the variables of the therapist that can affect the psychotherapies are sex, age, ethnicity, experience, personality, emotional well-being, values, beliefs and theoretical orientation, among others. Another aspect considered relevant among the variables of the therapist is the characteristics of the interventions performed during the psychotherapeutic process (Goodman et al., 2014). This study focuses on the types of interventions associated with the improvement or alteration of the process, thus identifying the so-called "active ingredients" of the therapeutic change (Banon et al., 2013; Roussos, Waizmann, \& Etchebarne, 2010).

It has been verified that therapists have a great influence on the results of the treatment (Owen, Drinane, Idigo, \& Valentine, 2015).
Despite advances in international literature and research in psychotherapy, studies based on the psychoanalytic model are still scarce. There are few Brazilian studies that have sought to investigate the variables of the therapists involved in the treatments (Quadros \& Yoshida, 2012).

It is possible to observe that over the years different emphases occurred in the understanding of the therapeutic action in the psychoanalytic approach. Although the interpretation, the insight and the aspects of the therapeutic interaction between analyst and patient are central methods in the therapeutic action, these elements are not identified as unique in the therapeutic process. Currently, psychoanalytic therapists recognize that there are multiple modes of therapeutic action that vary from patient to patient (Clarkin, Fonagy, \& Gabbard, 2013; Gabbard, 2005; Gabbard \& Westen, 2003). In this sense, there have been changes in the management of the psychotherapeutic technique for certain patients, especially in the treatment of patients with severe pathologies (Pasini \& Dametto, 2010). Quagliatto and Santos (2004) highlighted modifications in the management of the psychotherapeutic technique for certain patients, mainly those characterized as having severe psychopathologies: psychoses, borderline disorder, narcissistic disorder and psychopathies, among others.

Regarding the technical aspect of the interventions of the therapist, it has been verified that the basic techniques of psychoanalytic psychotherapy with BPD patients are the same as those of psychoanalysis: interpretation, transference analysis and technical neutrality. However, these techniques are used differently by the therapist (Kernberg, 2003; Kernberg, Selzer, Hoenigsberg, Carr, \& Appelbaum, 1991).

Kernberg (2003) stated that the clarification, confrontation and interpretation are the main aspects of the interpretive technique used in psychoanalytic psychotherapy. With patients with serious psychopathologies, the clarification and confrontation occupy a wider space than the interpretation, with the interpretations of unconscious meanings in the "here and now" having more space than those in the "there and then". 
Only in the more advanced stages of treatment are interpretations beyond the "here and now" introduced, so as to relate past behavior to the present. In addition, interpretations are most effective when presented to an emotionally prepared patient. Thus, the sequential use of clarification and confrontation opens the way for the interpretation itself.

Another basic technique of psychoanalysis, according to Kernberg (2003), is that of transference analysis, which constitutes the main focus of the interpretation in classical psychoanalysis. It is modified with patients with severe personality disorders when considering any transference interpretation in the context of what is occurring in the current life of the patient (Kernberg et al., 1991). Negative and positive transference of these patients should only be worked on in the "here and now" without attempting to achieve complete genetic reconstructions, since the lack of differentiation and individualization of the objects interferes in the ability to differentiate the present and past object relationships (Kernberg, 1995).

The technical neutrality of the therapist is also considered to be an essential element of the psychoanalytic method, which is highlighted as an ideal state of work. However, in patients with serious personality pathologies, the need to determine limits imposes temporary modifications in the technique to allow for the control of acting out that threatens the life of the patient or the treatment (Kernberg, 2003).

Despite the increase in knowledge regarding clinical work with severe patients, studies on the psychotherapeutic process in relation to the interventions of the therapist are still needed (Lambert, 2013; Quadros \& Yoshida, 2012). According to Banon et al. (2013), studies of the psychotherapy process require a descriptive basis for the characteristics of the technique of the therapist. Therefore, identifying interventions of the therapist facilitates studies of the process by elucidating connections between types of interventions and their effects on the process of change.

With regard to research, many of the studies investigate the interventions of therapists considering different theoretical approaches. A study by Banon et al., using the Psychodynamic Intervention Rating Scale (PIRS), aimed to evaluate the frequency and depth of the interventions of the therapist in psychodynamic, psychoanalytic and cognitive behavioral psychotherapies. Among the various results, it was mentioned that the proportions of interpretations increased over time, as did their depth. Defense interpretations were more common than transference interpretation, which were more prevalent in the psychoanalysis.

Some authors have devoted themselves to analyzing the interventions of the therapist regarding the psychoanalytic and cognitive behavioral theoretical frameworks. A study by Waizmann, Jurkowski and Roussos (2006), with the aim of verifying the mode of interventions of psychoanalytic and cognitive therapists, investigated the types of interventions they used in terms of specific and nonspecific interventions. Among the results, the authors observed that the therapists used specific interventions from another theoretical framework of reference, however, they remained faithful to their own framework in relation to the interventions they used most.

Conversely, a subsequent study by Roussos et al. (2010), using the Modified Multidimensional Classification of Psychotherapeutic Interventions (CMIP-M), found contradictory results. This instrument presents a methodology for the construction of a classificatory scheme for the psychoanalytic and cognitive behavioral interventions and aims to identify types of interventions in clinical material. The CMIP-M considers four levels of analysis of the interventions, these being: (1) strategic, (2) descriptive, (3) content and (4) space-temporal (Roussos, Etchebarne, \& Waizmann, 2005).

The authors used the descriptive level of the instrument, which evaluates the different types and forms of interventions, to examine the interventions used in two psychotherapeutic treatments, one cognitive and one psychoanalytic, both with a diagnosis of personality disorder. This descriptive level includes the following types of interventions: exploratory, empathic, 
explanatory, indicative, examination, with third parties (people outside the dyad) and unclassifiable. In addition, they investigated whether the interventions of the therapist were directly associated with their theoretical foundation, as well as the proportion of common, nonspecific and specific interventions. In the latter case, common interventions are those used by both theoretical frameworks, nonspecific interventions are those used by another theoretical framework other than that of the treating therapist and, specific interventions are those specific to the theoretical line of the psychotherapist (Roussos et al., 2005). The results showed that both treatments were highly impregnated by nonspecific interventions. A mean of $17 \%$ of the interventions in the psychoanalytic treatment and $16 \%$ in the cognitive treatment were specific to the respective theoretical frameworks. Differences found in the proportions of specific and common interventions can be justified by the assumption that both types of interventions interact and complement each other. Thus, common interventions may be paving the way for specific interventions, that is, their role in psychotherapy may be to generate the context and timing for specific interventions (Roussos et al., 2010).

It should be noted that the studies focus on the identification of therapeutic interventions according to the theoretical models, however, few investigate the psychotherapeutic interventions in the different clinical conditions. In relation to severe patients, there have been limited scientific investments that were dedicated to the study of psychotherapeutic interventions. Koenigsberg, Kernberg, Appelbaum, and Smith (1993) developed a method for analyzing the interventions of the therapist in Borderline patient psychotherapy, which monitors the use of the expressive technique and support in the sessions. Among the results found, the total percentage of expressive interventions (explanations, confrontation and interpretation) ranged from $68 \%$ to $98 \%$ throughout the 12 sessions analyzed, except for in one isolated case (43\%). The indices of clarification, confrontation and interpretation were uniform, without clear discrepancies. These sessions were conducted by ten therapists, who varied in length of experience and time since formation in psychoanalysis, and were a mixture of early and late sessions.

Some authors state that according to the symptoms of the patient in the course of the care, the therapists modify their interventions. In this case, Goodman et al. (2014) found that psychoanalytically oriented therapists, faced with severely impaired patients, require a temporary flexibility in the technique and adopt more structured interventions that serve to stabilize the treatment.

It has been observed that psychotherapies have been shown to be effective through different approaches and for different disorders, with both common factors and specific factors having been investigated and related to therapeutic success (Brum et al., 2012; Isolan, Pheula, \& Cordioli, 2008). However, there is a need for a greater number of studies aimed at identifying the interventions of the therapist in order to contribute to the advancement of knowledge regarding therapeutic action based on different theoretical approaches and clinical conditions.

Thus, this study aimed to identify the types of interventions used by a psychoanalytic therapist during the psychotherapy process of a patient with Borderline Personality Disorder, in a period of the treatment prior to her psychiatric hospitalization. The proportion of each type of intervention was verified throughout the process and, subsequently, in the three divided stages of the treatment. The proportion of common interventions and specific psychoanalytic interventions throughout the treatment analyzed was also investigated.

\section{Method}

\section{Participants}

The present case was an 18-year-old, female university student that sought treatment at a psychiatric clinic in Porto Alegre, a city located in the state of Rio Grande do Sul, Brazil. The young woman lived with her mother, her father having died during her childhood. In the screening interview the patient presented crying crises and reported several attempts to cut herself. She said 
that she had performed psychotherapy at various moments in her life, with a history of early abandonment of the treatments. After a period of time following the screening the patient was referred to individual psychoanalytic psychotherapy with frequency of twice a week and also for psychiatric evaluation. The diagnosis made by the psychiatrist during the initial stage of the psychotherapeutic treatment was of Borderline Personality Disorder. The patient started antidepressant drug treatment and, during the period of the psychotherapeutic process investigated, there was no change in the dosage or medication.

The therapist was trained in psychoanalytic psychotherapy and had psychodynamic authors as the reference. Her practice was based on threefold training: theoretical seminars, supervision and personal treatment. She had ten years of experience in psychotherapeutic care. It should be noted that the researcher was not the therapist in the case under study.

\section{Instrument}

In this study, the Modified Multidimensional Classification of Psychotherapeutic Interventions (CMIP-M), developed by Roussos et al. (2005) was used. The instrument was translated from Spanish into Portuguese by a professional proficient in Spanish with a background in Psychology, with the back-translation then carried out by another bilingual professional.

The CMIP-M presents a methodology for the construction of a classificatory scheme of psychoanalytic and cognitive-behavioral psychotherapeutic interventions. It aims to construct a comprehension scheme to identify types of interventions in clinical material (Roussos et al., 2005).

According to these authors, the CMIP-M considers four levels of analysis of the interventions, these being: (1) strategic, (2) descriptive, (3) content and (4) space-temporal. The levels present interactions among themselves, however, can be evaluated independently, since they represent different aspects of the same event. In the present study, the interventions of a psychoanalytic therapist were evaluated considering only the descriptive level.
The descriptive level evaluates the verbalizations performed by the therapist that are intentionally directed towards the patient. It is the exclusive study of the different types and forms of interventions. In order to classify the descriptive level of the interventions, the conceptualization of the theoretical framework of the treating therapist, psychoanalytic or cognitive behavioral, should always be respected, as the CMIP$M$ presents subtypes of groups of interventions common to both theoretical frameworks, psychoanalytic subtypes, cognitive subtypes and behavioral subtypes (Roussos et al., 2005).

Regarding the descriptive interventions specific to the psychoanalytic framework and common to both frameworks, seven groups of interventions can be considered. These are: (1) Exploratory (open information request, closed information request, application of scales and questionnaires); (2) Empathic (anticipation, repetition, synthesis, phatic order, acquiescence, support); (3) Explanatory (general explanation, psychological explanation, meta intervention, interpretation, transference interpretation); (4) Indicative (suggestion or advice, definition of limits, framing instructions, free association); (5) Examination (recapitulation, signaling, confrontation); (6) With third parties (people outside the dyad) and (7) Unclassifiable. Three of these groups involve psychoanalytic specific interventions, with interpretation and transference interpretation, within the group of explanatory interventions, free association, within the group of indicative interventions and signaling and confrontation, within the group of examination interventions, being psychoanalytic specific (Roussos et al., 2005). It is emphasized that signaling is understood as the enlightenment (clarification) interventions.

The CMIP-M, developed based on the theoretical investigation and qualitative analysis of audio recordings of clinical sessions (Roussos et al., 2010), has already been used in other studies with the aim of analyzing psychotherapeutic interventions. Authors such as Roussos et al. (2010) and Waizmann et al. (2006) used the CMIP-M in their studies and did not mention any limitations regarding the instrument. 


\section{Data Collection Procedures}

All the psychotherapy sessions were recorded on video. For this study, 12 sessions, of a total of 34 that preceded the psychiatric hospitalization of the patient, were transcribed and analyzed. This period corresponds to the first year of the treatment of the patient, and included the following sessions: $1,4,7,10,13,16,19,22$, $25,28,31$ and 34 . The sessions were chosen randomly, considering 1 in every 3 sessions, aiming to accompany the evolution of the case without losing specificity.

\section{Data Analysis Procedures}

Pairs of independent judges, trained in the CMIP-M evaluation methodology, watched the recordings of the sessions and, in possession of their transcripts and the instruction manual of the instrument, evaluated the psychotherapy sessions in order to classify each of the interventions of the therapist at the descriptive level. In order to verify the reliability of the classifications, the author of the instrument supervised a session and the coefficient of variability among the judges (Kappa) was calculated, showing a concordance higher than 0.7 in all the sessions investigated. Three duly trained judges participated in the classification procedures, with a rotation in the formation of the pairs.

The types of interventions were evaluated quantitatively and all analyses were performed using the Statistical Package for the Social Sciences (SPSS) version 20.0. The results are presented through descriptive statistics of frequency and percentage.

In addition, three treatment steps were identified, these being: (1) initial, (2) intermediate and (3) prior to hospitalization. The first four sessions (1, 4, 7 and 10) corresponded to the initial stage of treatment, the four following sessions (13, 16, 19 and 22) corresponded to the second or intermediate stage and the later sessions investigated $(25,28,31$ and 34) corresponded to the third stage of the treatment, which preceded the psychiatric hospitalization of the patient.
Finally, the interventions were analyzed for their specificity, and the proportion of specific psychoanalytic interventions common to both theoretical frameworks was verified. The verbalizations performed by the therapist that are specific to the psychoanalytic theoretical framework (Waizmann, Etchebarne, \& Roussos, 2004) were termed "psychoanalytic specific interventions". According to the designation of these authors, those verbalizations of the therapist that are not an explicit part of their theoretical orientation but are used in both forms of psychotherapy (Psychoanalytic and Cognitive-Behavioral) were considered to be "common interventions".

\section{Ethical Procedures}

The patient and the therapist read and signed the consent form. All the ethical guidelines of Resolution No. 466/2012 of the National Health Council were followed (2012), with the therapist and patient agreeing to the video recording of the sessions.

\section{Results}

All the verbal interventions of the therapist were considered during each of the 12 sessions and classified according to the descriptive level of the CMIP-M. The results are presented in Figure 1 , which shows the frequency distributions of each type of therapeutic intervention used throughout the process investigated. It should be noted that the empathic interventions predominated, with $27.3 \%$, followed by closed exploratory, which reached a percentage of $24.1 \%$. These interventions were followed by psychoanalytic examination (15.1\%), open exploratory (13.1\%) and unclassifiable $(12.1 \%)$. The lowest frequencies occurred for the psychoanalytic explanatory $(0.2 \%)$, common examination $(0.7 \%)$, common indicative $(2.5 \%)$ and common explanatory $(5.1 \%)$ interventions. Indicative psychoanalytic interventions and those with third parties did not occur in the process investigated. 




Figure 1. Proportion of each type of intervention throughout the process investigated.

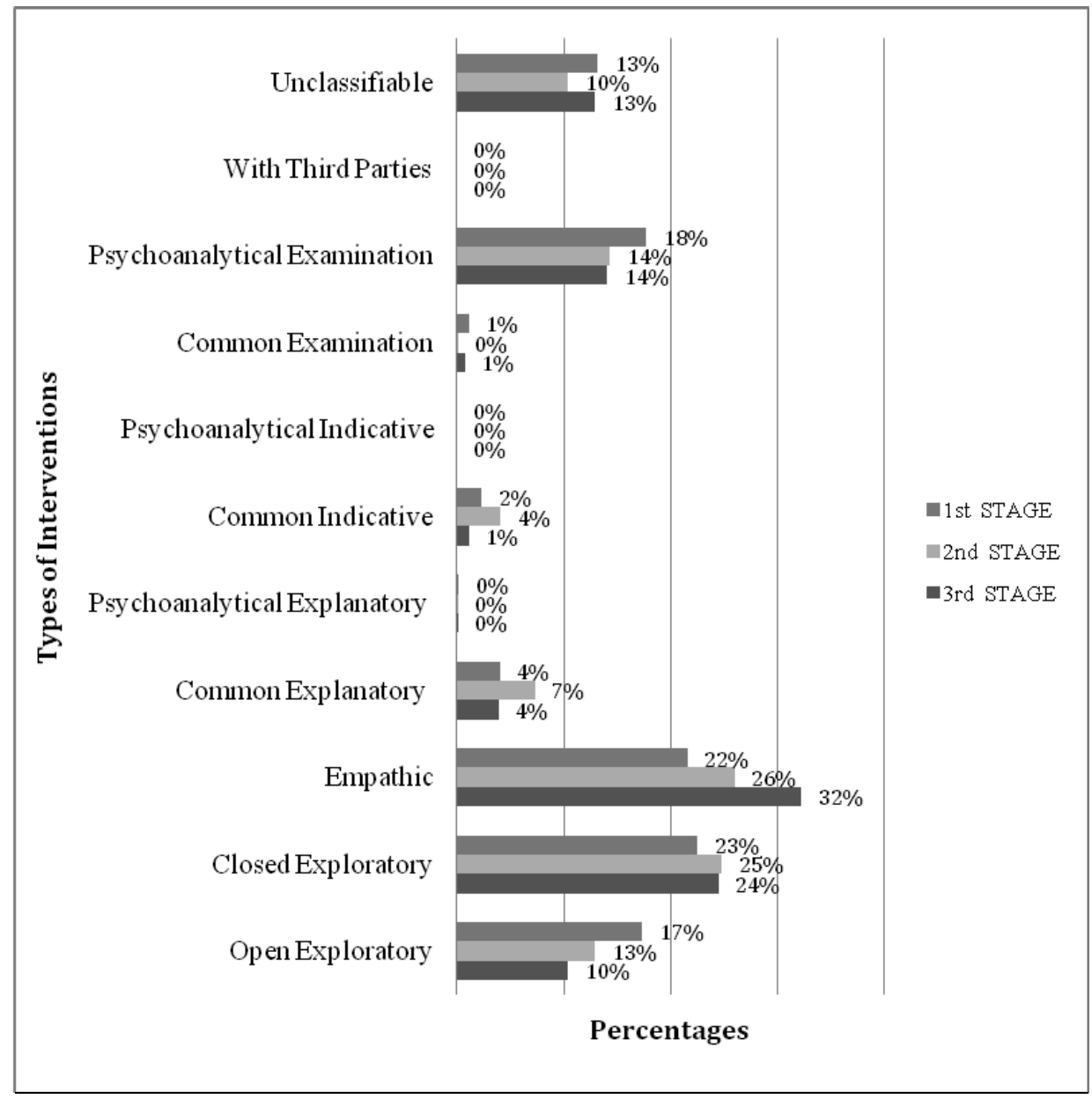

Figure 2. Predominant interventions by treatment stage. 
In this study three stages were also identified, which were explored in relation to the predominant interventions. Figure 2 shows that empathic and closed exploratory interventions predominated in all stages. Thus, in the first stage of the psychotherapeutic process, closed exploratory interventions $(23 \%)$ were followed by the empathic $(22 \%)$, in the second stage empathic interventions $(26 \%)$ were followed by the closed exploratory (25\%) and in the third stage, the maximum frequency occurred for empathic interventions (32\%) followed by closed exploratory $(24 \%)$.

The specific analysis of these proportions indicates that the maximum oscillation of each type of intervention per stage was $10 \%$. This change in frequency occurred between the first and third stages in relation to empathic interventions. The other types of intervention maintained equivalent proportions throughout the three stages of the process investigated. In observing the work of the therapist throughout the treatment in relation to empathic interventions, it was verified that the increase of this type of intervention in the third stage corresponded to work focused more on the situation of the patient in crisis, since these sessions correspond to the period prior to hospitalization.

Finally, when analyzing the proportion of common interventions and psychoanalytic specific interventions throughout the psychotherapeutic process investigated, $15 \%$ of the interventions were specific to the psychoanalytic orientation, while $85 \%$ were common interventions. Thus, it was observed that the interventions were characterized, for the most part, as common, that is, they are used in psychoanalytic and cognitive-behavioral treatments.

\section{Discussion}

This study aimed to investigate the therapeutic action in the model of psychoanalytic orientation of psychotherapy directed toward severe patients, specifically considering the contribution of the therapist in the process. One aim was to identify the types of interventions used by a psychoanalytic therapist during the psycho- therapy process of a patient with Borderline Personality Disorder. The evaluation of the proportion of each type of intervention throughout the process investigated revealed that empathic and closed exploratory interventions predominated. The third type of intervention more used by the therapist of the case was the psychoanalytic examination intervention.

The types of interventions employed by the therapist in greater proportions seem to be consistent with the model of BPD patient functioning. This is characterized by serious self-aggression behaviors and suicidal attitudes (Madeddu et al., 2012), frequent acting out, tendency toward impulsivity and aggressiveness (Bleichmar, 1992; Hallquist \& Pilkonis, 2012) and difficulties in adherence to treatment (Tanesi et al., 2007).

In considering these characteristics, the therapist more frequently used empathic interventions, since this therapeutic posture contributes to adaptation of the patient and the establishment of the bond. Some authors highlight that establishing a therapeutic alliance with severe patients is very important for the management of the treatment, since these patients have particular characteristics that influence their adherence and also the decision regarding the use of the technique by the psychotherapist (Owen \& Hilsenroth, 2011). It was observed that the therapist was focused on establishing a therapeutic alliance, since the quality of the bond is a strong predictor of results (Elliot, 2012).

The empathic attitude of the therapist, according to Ablon and Jones (1998), is in accordance with the therapeutic techniques of the psychoanalytic approach. The authors state that the psychoanalytic based model stands out due to the position of the therapist being neutral, empathic and sensitive to the feelings of the patient.

The second type of intervention most used was the closed explorative, when the therapist requests information, introducing discussion topics. In general, the use of interrogative interventions characterize a more active and directive posture of the therapist. Generally, these are more commonly used in the cognitive model of treatment. However, in the case of patients with serious psychopathologies, psychoanalytic ther- 
apists make the technique more flexible in order to stabilize the treatment (Goodman, Edwards, \& Chung, 2013).

In this sense, Goodman et al. (2013) analyzed the psychotherapeutic process of five BPD patients associated with different therapeutic models. In this study, the empathic posture correlated with symptomatic reduction. Similarly, the therapist actively exercising control of the interaction, questioning and requesting more information, was associated with symptomatic reduction. According to the researchers, the use of these strategies by psychodynamic therapists indicates the effort to maintain the stability of severe patients and the therapeutic alliance, when faced with symptomatic intensification.

Thus, the prevalence of the empathic and closed exploratory interventions in the investigated process can be related to the symptomatology of the patient and to the diagnosis of the case. On the other hand, the preponderance of such interventions may also be associated with the particularities of the therapist. Therefore, it is possible to question how much the results refer to the Borderline diagnosis and its symptomatology or the therapist, since authors such as Fernández-Alvarez, Gomez, and Garcia (2015) and Lambert (2013) verified that the psychotherapist can influence the development and the results of the psychotherapeutic process.

Considering these questions, in relation to the studies already performed, different results have been observed. On one hand, similar to the present study, Roussos et al. (2010), using the CMIP-M as the instrument, analyzed the interventions in a psychoanalytic treatment with a diagnosis of unspecified personality disorder and verified a higher proportion of closed interrogation interventions. On the other hand, a study by Koenigsberg et al. (1993), using the Therapist Verbal Intervention Inventory (TVII) and aiming to analyze the interventions of the therapist in the psychotherapy with Borderline patients and to monitor the use of the expressive technique (explanations, confrontation and interpretation) and support, found a predominance of expressive interventions, which varied uniformly from $68 \%$ to $98 \%$ throughout the 12 sessions analyzed, except for one isolated case of $43 \%$. These results contradict those found in the present study, in which psychoanalytical examination interventions (signaling and confrontation) ranked third in the classification of those most used in the treatment, reaching a percentage of $15.1 \%$, and psychoanalytic explanatory interventions (interpretation) reaching a percentage of $0.2 \%$ in the process investigated.

However, even in lower proportions than the study by Koenigsberg et al. (1993), in the present study the percentage of psychoanalytical examination interventions (15.1\%) was significantly higher than the psychoanalytic explanatory interventions $(0.2 \%)$. According to Kernberg (2003), in psychoanalytic psychotherapy with patients with Borderline Personality Disorder, interventions such as signaling and confrontation occupy a much wider space than interpretation.

The results of the present study are in agreement with the literature, which, in the case of patients with fewer resources, suggests supportive psychotherapy, that is, a preference for interventions that are not focused on transference (Gabbard, 1984/1998). Leichsenring and Leibing (2007) state that supportive interventions aim to strengthen skills that are temporarily unavailable to a patient due to acute stress (e.g., traumatic events) or that have not been sufficiently developed (e.g. impulse control in Borderline Personality Disorder).

On the other hand, analyzing the interventions in relation to the stages of the treatment, it is possible to verify that the types of interventions that predominated in the three stages of the process coincided and there was a preponderance of the empathic and closed exploratory interventions throughout the treatment. Thus, the therapist maintained the same types of interventions and appeared to strive to develop a therapeutic alliance between the two and adopt a more directive posture.

A more specific analysis of each type of intervention indicates that between the first and second stages there was no significant change in the proportions of each type of intervention. However, in the third stage, which preceded the 
psychiatric hospitalization of the patient, there was an increase in the percentage of empathic interventions. Thus, this demonstrates the ability of the therapist to tune in to the situation of the patient in crisis and to make the technique flexible, increasing the use of empathic interventions. This attitude of the therapist is in agreement with the literature in that therapists modify their interventions according to the symptoms of the patient (Goodman et al., 2014).

The analysis of the specific and common interventions in the case of the Borderline patient studied indicated that $15 \%$ of the interventions used during the process investigated were psychoanalytic specific, while $85 \%$ were common interventions, which are not explicitly part of the theoretical framework of the therapist and are used in psychoanalytic and cognitive behavioral treatments. The results obtained in the present study coincide with the results found by Roussos et al. (2010), who used the descriptive level of the same instrument (CMIP-M) to examine the interventions used in two psychotherapeutic treatments: one cognitive with a diagnosis of generalized anxiety disorder and one of psychoanalytic orientation with a diagnosis of unspecified personality disorder, and found that a mean of $17 \%$ of the interventions in the psychoanalytic treatment and a mean of $16 \%$ in the cognitive treatment were specific to the respective theoretical frameworks.

From the results of the studies, it can be seen that the percentage of specific interventions of each theoretical framework remains similar in cases of personality disorder. Some authors have suggested that psychotherapies have been shown to be effective through different approaches and for different disorders, with both common factors and specific factors having been investigated and related to therapeutic success (Brum et al., 2012; Isolan et al., 2008). Authors such as Roussos et al. (2010) suggest that the nonspecific factors may be the main promoters of change in psychotherapy, and that nonspecific factors should be studied in order to find their connections with specific factors and, through this, to establish the factors that promote change in psychotherapy. Other scholars such as Gumz, Treese, Marx,
Strauss, and Wendt (2015) and Pfammatter and Tschacher (2012) have highlighted that the technique and the common factors cannot be considered independently. The common factors evolve in the context of the therapeutic relationship, which, in turn, is influenced to a great extent by the techniques.

According to Roussos et al. (2010), a possible justification for the differences found in the proportions of nonspecific and specific interventions could be that both types of interventions interact and complement each other. Considering this assumption, nonspecific interventions could be paving the way for specific interventions, that is, their role in psychotherapy would be to generate the right context for specific interventions. The authors mention that while psychoanalysts do not interpret, signal, or confront their patients, they are certainly not in complete silence all the time. They use nonspecific interventions - such as information requests and closed interrogations - to retrieve the necessary input or to generate the right moment to perform an accurate interpretation. Therefore, nonspecific interventions can be conceived as "preparatory interventions" or as part of the natural environment of specific interventions.

\section{Final Considerations}

Given the importance of improving the psychotherapeutic work with BPD patients, this study aimed to identify the types of interventions of a psychoanalytic therapist in the psychotherapy of a patient with Borderline Personality Disorder. Thus, it was sought to contribute to the investigation of the therapeutic action in the psychoanalytic model of psychotherapy, specifically considering the contribution of the therapist in the process. Investigating the interventions performed throughout the therapeutic process allows support for both the study of the difficulties of choosing the technique and modality of interventions, as well as the teaching of the performance of psychoanalytic oriented psychotherapy with these patients.

The interventions that supported the process investigated were empathic, closed exploratory 
and psychoanalytic examination interventions. In this sense, it was observed that the therapist privileged the development of the therapeutic alliance and the support to the patient, adopting a more directive posture, even though psychoanalytic interventions were used less frequently.

As a descriptive study, it is hoped that this paves the way for new research, since the study presents limitations especially with regard to the generalization of the data. Further studies are important to confirm whether the choice of interventions used in this case was due to the characteristics of patients with BPD or the particularities of the therapist, as well as to investigate specific and common factors and their relationship with therapeutic success.

\section{References}

Ablon, J. S., \& Jones, E. E. (1998). How expert clinicians' prototypes of an ideal treatment correlate with outcome in psychodynamic and cognitive-behavioral therapy. Psychotherapy Research, 8(1), 71-83. doi: 10.1080/10503309812331332207

Banon, E., Perry, J. C., Semeniuk, T., Bond, M., Roten, Y., Hersoug, A. G., \& Despland, J. N. (2013). Therapist interventions using the Psychodynamic Interventions Rating Scale (PIRS) in dynamic therapy, psychoanalysis and CBT. Psychotherapy Research, 23(2), 121-136. doi: 10.1080/10503307.2012.745955

Bleichmar, N. M. (1992). A psicanálise depois de Freud. Porto Alegre, RS: Artes Médicas.

Brum, E. H. M., Frizzo, G. B., Gomes, A. G., Silva, M. R., de Souza, D. D., \& Piccinini, C. A. (2012). Evolução dos modelos de pesquisa em psicoterapia. Estudos de Psicologia (Campinas), 29(2), 259-169. doi: 10.1590/S0103$166 \times 2012000200012$

Clarkin, J. F., Fonagy, P., \& Gabbard, G. O. (2013). Psicoterapia psicodinâmica para transtorno da personalidade: Um manual clínico. Porto Alegre, RS: Artmed.

Cordioli, A. V., \& Giglio, L. (2008). Como atuam as psicoterapias: Os agentes de mudança e as principais estratégias psicoterápicas. In A. V. Cordioli (Ed.), Psicoterapias: Abordagens atuais (pp. 42-57). Porto Alegre, RS: Artmed.
Eizirik, M., \& Fonagy, P. (2009). Mentalization-based treatment for patients with borderline personality disorder: An overview. Revista Brasileira Psiquiatria, 31(1), 72-75. doi: 10.1590/S151644462009000100016

Elliot, R. (2012). Qualitative Methods for Studying Psychotherapy change Process: A guide for students and practitioners. Washington, DC: Wiley.

Fernández-Alvarez, H., Gómez, B., \& García, F. (2015). Bridging the gap between research and practice in a clinical and training network: Aigle's Program. Psychotherapy Research, 25(1), 8494. doi: 10.1080/10503307.2013.856047

Fonagy, P., \& Bateman, A. W. (2007). Mentalizing and borderline personality disorder. Journal of Mental Health, 16(1), 83-101. Retrieved from http://www.ncbi.nlm.nih.gov/pmc/articles/ PMC2816926/

Gabbard, G. O. (1998). Psiquiatria psicodinâmica: Baseado no DSM-IV (2 ${ }^{\text {nd }} E d$.) Porto Alegre, RS: Artes Médicas. (Original work published in 1984)

Gabbard, G. O. (2005). Psicoterapia psicodinâmica de longo prazo: Texto básico. Porto Alegre, RS: Artmed.

Gabbard, G. O., \& Westen, D. (2003). Repensando a ação terapêutica. Revista Psiquiatria, 25(2), 257 273. doi: 10.1590/S0101-81082003000200003

Goodman, G., Anderson, K., \& Diener, M. J. (2014). Processes of therapeutic change in psychodynamic therapy of two inpatients with borderline personality disorder. Journal of Psychotherapy Integration, 24(1), 30-45. doi: 10.1037/ a0035970

Goodman, G., Edwards, K., \& Chung, H. (2013). The relation between prototypical processes and psychological distress in psychodynamic therapy of five inpatients with borderline personality disorder. Clinical Psychology and Psychotherapy, 22(1), 83-95. doi: 10.1002/cpp.1875

Gumz, A., Treese, B., Marx, C., Strauss, B., \& Wendt, H. (2015). Measuring verbal psychotherapeutic techniques: A systematic review of intervention characteristics and measures. Frotiers in Psychology, 6(1705). doi: 10.3389/ fpsyg.2015.01705

Hallquist, M. N., \& Pilkonis, P. A. (2012). Refining the phenotype of borderline personality disor- 
der: Diagnostic criteria and beyond. Personality Disorders: Theory, Research, and Treatment, 3(3), 228-246. doi: 10.1037/a0027953

Heinomen, E., Knekt, P., Jääskeläinen, T., \& Lindfors, O. (2014). Therapists` professional and personal characteristics as predictors of outcome in long-term psychodynamic psychotherapy and psychoanalysis. European Psychiatry, 29, $265-$ 274. Retrieved from http://www.ncbi.nlm.nih. gov/pubmed/24060629

Isolan, L., Pheula, G., \& Cordioli, A. V. (2008). Fatores comuns e mudanças em psicoterapia. In A. V. Cordioli (Ed.), Psicoterapias: Abordagens atuais (pp 58-73). Porto Alegre, RS: Artmed.

Jordão, A. B., \& Ramires, V. R. R. (2010). Adolescência e organização de personalidade borderline: Caracterização dos vínculos afetivos. Paidéia (Ribeirão Preto), 20(47), 421-430. doi: $10.1590 / \mathrm{S} 0103-863 \times 2010000300014$

Kernberg, O. F. (1995). Transtornos graves de personalidade: Estratégias psicoterapêuticas. Porto Alegre, RS: Artes Médicas.

Kernberg, O. F. (2003). Psicanálise, psicoterapia psicanalítica e psicoterapia de apoio: Controvérsias contemporâneas. In A. Green (Ed.), Psicanálise contemporânea: Revista Francesa de psicanálise (pp. 23-49). Rio de Janeiro, RJ: Imago.

Kernberg, O. F., Selzer, M. A., Koenigsberg, H. W., Carr, A. C., \& Appelbaum, A. H. (1991). Psicoterapia psicodinâmica de pacientes borderline. Porto Alegre, RS: Artes Médicas.

Koenigsberg, H. W., Kernberg, O. F., Appelbaum, A. H., \& Smith, T. (1993). A method for analyzing therapist interventions in the psychotherapy of borderline patients. Journal of Psychotherapy Practice and Research, 2(2), 119-134. Retrieved from http://www.ncbi.nlm.nih.gov/pmc/articles/ PMC3330333/

Lambert, M. (2013). Bergin and Garfield's handbook of psychotherapy and behavior change. In K. A. Tompkins \& J. K. Swift (Eds.), Psychotherapy Process Outcome Research. Hoboken, NJ: John Willey \& Sons.

Leichsenring, F., \& Leibing, E. (2007). Psychodynamic psychotherapy: A systematic review of techniques, indications and empirical evidence. Psychology and Psychotherapy: Theory, Research and Practice, 80, 217-228. doi: 10.1348/147608306X117394
Madeddu, F., Aquaro, P., \& Preti, E. (2012). Psicoterapia per il disturbo borderline di personalità: revision della letteratura sull'efficacia di quattro trattamenti manualizzati. Journal of Psychopathology, 18, 196-209. Retrieved from http://www.jpsychopathol.it/issues/2012/vol183/02Madeddu.pdf

Owen, J., Drinane, J. M., Idigo, K. C., \& Valentine, J. C. (2015). Psychotherapist effects in metaanalyses: How accurate are treatment effects? Psychotherapy, 52(3), 321-328. Retrieved from http://psycnet.apa.org/journals/pst/52/3/321.pdf

Owen, J., \& Hilsenroth, M. J. (2011). Interaction between alliance and technique in predicting patient outcome during psychodynamic psychotherapy. The Journal of Nervous and Mental Disease, 199(6), 384-389. doi: 10.1097/ NMD.0b013e31821cd28a.

Pasini, T. F., \& Dametto, J. (2010). Abordagem psicodinâmica do paciente borderline. Perspectiva, 34(128), 133-149. Retrieved from http:// pt.slideshare.net/cinthyabretas/paciente-borderline-e-seu-tratamento-pdf

Peuker, A. C., Habigzang, L. F., Koller, S. H., \& Araujo, L. B. (2009). Avaliação de processo e resultado em psicoterapias: Uma revisão. Psicologia em Estudo, 14(3), 439-445. doi: 10.1590/ S1413-73722009000300004

Pfammatter, M., \& Tschacher, W. (2012). Wirkfaktoren der Psychotherapie: eine Übersicht und Standortbestimmung. Zeitschrift für Psychiatrie Psychologie und Psychotherapie, 60, 67-76. doi 10.1024/1661 - 4747/a000099

Quadros, E. A., \& Yoshida, E. M. P. (2012). Variáveis do terapeuta: Análise em periódicos brasileiros (1998-2007). Interação Psicologia, 16(1), 6372. Retrieved from http://ojs.c3sl.ufpr.br/ojs/ index.php/psicologia/article/view/11546/19716

Quagliatto, H. S. M., \& Santos, R. G. (2004). Psicoterapia psicanalítica e acompanhamento terapêutico: Uma aliança de trabalho. Psicologia Ciência e Profissão, 24(1), 74-81. doi: 10.1590/ s1414-98932004000100009

Resolution No. 466. (2012). Diretrizes e normas regulamentadoras de pesquisas envolvendo seres humanos. Retrieved from http://conselho.saude. gov.br/resolucoes/2012/Reso466.pdf

Roussos, A. J., Etchebarne, I., \& Waizmann, V. (2005). Un esquema clasificatorio para lãsintervenciones en psicoterapia cognitiva y psico- 
analítica. Anuario de Investigaciones, 8, 41-48. Retrieved from http://www.scielo.org.ar/pdf/ anuinv/v13/v13a05.pdf

Roussos, A. J., Waizmann, V., \& Etchebarne, I. (2010). Common Interventions in two single cases of cognitive and psychoanalytic psychotherapies. Journal of Psychotherapy Integration, 20(3), 327-346. Retrieved from http://psycnet.apa.org/index.cfm?fa=buy. optionToBuy\&id=2010-17586-004

Tanesi, P. H. V., Yazigi, L., Fiore, M. L. M., \& Pitta, J. C. N. (2007). Adesão ao tratamento clínico no transtorno de personalidade borderline. Estudos de Psicologia (Natal), 12(1), 71-78. Retrieved from http://www.scielo.br/pdf/epsic/v12n1/ a09v12n1.pdf

Waizmann, V., Etchebarne, I., \& Roussos, A. J. (2004). La interacción entre las intervenciones psicorapéuticas de distintos marcos teóricos y los factores comunes a las psicoterapias. Revista
Argentina de Clínica Psicológica, 13(3), 233244. Retrieved from: http://www.academia. $\mathrm{edu} / 3996581 / \mathrm{La}$ interacci\%C3\%B3n entre las_intervenciones_psicorap $\% \mathrm{C} 3 \% \mathrm{~A} 9 \mathrm{uticas}$ de_distintos_marcos_te $\%$ C3\%B3ricos_y_ los_factores_comunes_a_las_psicoterapias Waizmann_Etchebarne_and_Roussos_2004_

Waizmann, V., Jurkowski, L., \& Roussos, A., J. (2006). Descripción de las intervenciones elegidas por psicoterapeutas psicoanalíticos y cognitivos. Anuario de Investigaciones, 14, 41-48. Retrieved from http://www.scielo.org.ar/pdf/ anuinv/v14/v14a04.pdf
Received: 23/09/2016

$1^{\text {st }}$ revision: 11/04/2017

Accepted: 30/08/2017 